\title{
Serotonin Activates the Hypothalamic-Pituitary-Adrenal Axis via Serotonin 2C Receptor Stimulation
}

\author{
Lora K. Heisler, ${ }^{1}$ Nina Pronchuk, ${ }^{2}$ Katsunori Nonogaki, ${ }^{3,4}$ Ligang Zhou, ${ }^{1}$ Jacob Raber, ${ }^{5}$ Loraine Tung, ${ }^{1}$ Giles S. H. Yeo, ${ }^{1}$ \\ Stephen 0'Rahilly, ${ }^{1}$ William F. Colmers, ${ }^{2}$ Joel K. Elmquist, ${ }^{6}$ and Laurence H. Tecott ${ }^{3}$ \\ ${ }^{1}$ Department of Clinical Biochemistry, Addenbrooke's Hospital and the University of Cambridge, Cambridge CB2 2QR, United Kingdom, ${ }^{2}$ Department of \\ Pharmacology, University of Alberta, Edmonton, Alberta, Canada T6G 2H7, ${ }^{3}$ Department of Psychiatry and Center for Neurobiology and Psychiatry, \\ University of California at San Francisco, San Francisco, California 94117, ${ }^{4}$ Division of Molecular Metabolism and Diabetes, Tohoku University Graduate \\ School of Medicine, Miyagi 980-8575, Japan, ${ }^{5}$ Departments of Behavioral Neuroscience and Neurology, Division of Neuroscience, Oregon National Primate \\ Research Center, Oregon Health \& Science University, Portland, Oregon 97239, and ${ }^{6}$ Departments of Internal Medicine and Pharmacology, The University \\ of Texas Southwestern Medical Center, Dallas, Texas 75390
}

The dynamic interplay between serotonin [5-hydroxytryptamine (5-HT)] neurotransmission and the hypothalamic-pituitary-adrenal (HPA) axis has been extensively studied over the past 30 years, but the underlying mechanism of this interaction has not been defined. A possibility receiving little attention is that 5 -HT regulates upstream corticotropin-releasing hormone (CRH) signaling systems via activation of serotonin $2 \mathrm{C}$ receptors $\left(5-\mathrm{HT}_{2 \mathrm{C}} \mathrm{Rs}\right)$ in the paraventricular nucleus of the hypothalamus $(\mathrm{PVH})$. Through complementary approaches in wild-type rodents and 5- $\mathrm{HT}_{2 \mathrm{C}} \mathrm{R}$-deficient mice, we determined that $5-\mathrm{HT}_{2 \mathrm{C}} \mathrm{Rs}$ are necessary for 5-HT-induced $\mathrm{HPA}$ axis activation. We used laser-capture PVH microdissection followed by microarray analysis to compare the expression of 13 5-HTRs. Only $5-\mathrm{HT}_{2 \mathrm{C}} \mathrm{R}$ and $5-\mathrm{HT}_{1 \mathrm{D}} \mathrm{R}$ transcripts were consistently identified as present in the $\mathrm{PVH}$, and of these, the $5-\mathrm{HT}_{2 \mathrm{C}} \mathrm{R}$ was expressed at a substantially higher level. The abundant expression of $5-\mathrm{HT}_{2 \mathrm{C}} \mathrm{Rs}$ in the $\mathrm{PVH}$ was confirmed with in situ hybridization histochemistry. Dual-neurohistochemical labeling revealed that approximately one-half of PVH CRH-containing neurons coexpressed 5- $\mathrm{HT}_{2 \mathrm{C}} \mathrm{R}$ mRNA. We observed that PVH CRH neurons consistently depolarized in the presence of a high-affinity $5-\mathrm{HT}_{2 \mathrm{C}} \mathrm{R}$ agonist, an effect blocked by a $5-\mathrm{HT}_{2 \mathrm{C}} \mathrm{R}$ antagonist. Supporting the importance of $5-\mathrm{HT}_{2 \mathrm{C}} \mathrm{Rs}$ in $\mathrm{CRH}$ neuronal activity, genetic inactivation of $5-\mathrm{HT}_{2 \mathrm{C}} \mathrm{Rs}$ produced a downregulation of CRH mRNA and blunted $\mathrm{CRH}$ and corticosterone release after 5-HT compound administration. These findings thus provide a mechanistic explanation for the longstanding observation of HPA axis stimulation in response to 5 -HT and thereby give insight into the neural circuitry mediating the complex neuroendocrine responses to stress.

Key words: serotonin; 5- $\mathrm{HT}_{2 \mathrm{C}}$ receptor; $\mathrm{mCPP}$; corticotropin-releasing hormone; paraventricular nucleus of the hypothalamus; corticosterone

\section{Introduction}

Dysregulation of the hypothalamic-pituitary-adrenal (HPA) axis and 5-HT system has been implicated in the pathophysiology of disease states such as affective disorders, anxiety disorders, and obesity (Kelly et al., 1980; Heisler et al., 1998, 2003; Lucki, 1998; Porter et al., 2004). HPA axis activity is mediated by multiple central and peripheral inputs converging on the paraventricular

Received June 20, 2006; revised April 25, 2007; accepted April 25, 2007.

This work was supported by National Institute of Diabetes and Digestive and Kidney Diseases (NIDDK) Grant R01DK65171, the National Alliance for Research on Schizophrenia and Depression, and the Bank of AmericaGiannini Foundation (L.K.H.); Scientific Research (C2) and Takeda Research Foundation (K.N.); the Wellcome Trust (G.S.H.Y., S.O'R.); the Medical Research Council (L.T., S.O'R.); National Institute of Mental Health (NIMH) Grant R01MH061583 and NIDDK Grant P01DK056116 (J.K.E.); NIMH Grant R01MH61624 and the EJLB Foundation (L.H.T.); National Institutes of Health Grant R01AG20904 and Ellison Medical Foundation Grant AG-NS-0201 (J.R.); and Canadian Institutes of Health Research Grant MT 10520 and Merck Research Laboratories (W.F.C.).

Correspondence should be addressed to either of the following: Dr. Joel K. Elmquist, Departments of Internal Medicine and Pharmacology, Division of Hypothalamic Research, The University of Texas Southwestern Medical Center, 5323 Harry Hines Boulevard, Dallas, TX75390-9051, E-mail: joel.elmquist@UTSouthwestern.edu; or Dr. Lora K. Heisler, Department of Clinical Biochemistry, Addenbrooke's Hospital, Hills Road, University of Cambridge, Cambridge CB2 2QQ, UK, E-mail: Ikh30@medschl.cam.ac.uk.

DOI:10.1523/JNEUROSCI.2584-06.2007

Copyright $\odot 2007$ Society for Neuroscience $\quad$ 0270-6474/07/276956-09\$15.00/0 nucleus of the hypothalamus $(\mathrm{PVH})$, where corticotropinreleasing hormone $(\mathrm{CRH})$ is synthesized before its regulated release from the median eminence into the hypophyseal portal circulation (Guillemin and Rosenberg, 1955; Spiess et al., 1981). This stimulates the release of adrenocorticotropin (ACTH) from the anterior lobe of the pituitary, which in turn acts on the adrenal cortex to trigger the release of glucocorticoids, such as corticosterone/cortisol (CORT), into the bloodstream. Enhanced 5-HT neurotransmission produces potent and consistent increases in plasma concentrations of CORT, whereas depletion of the 5-HT precursor or 5-HT transporter reduces CORT (Fuller and Snoddy, 1980, 1990; Silverstone et al., 1994; Vielhaber et al., 2005). The prevalent use of compounds augmenting the synaptic availability of 5-HT and the alterations in adiposity and mood induced by CORT excess or deficiency highlight the importance of understanding this cross talk (Kelly et al., 1980; Gold and Chrousos, 1985; Bagdy et al., 1989; Laferrere et al., 1994; Vielhaber et al., 2005).

We hypothesized that 5-HT stimulates the HPA axis via action at $\mathrm{CRH}$-containing neurons in the brain, which subsequently augments CORT release. 5-HT-immunoreactive nerve termi- 
nals, although not densely evident within the PVH, are expressed in a pattern consistent with CRH-expressing cells (Sawchenko et al., 1983). Furthermore, light and electron microscopic immunocytochemistry has illustrated a synaptic interaction between 5-HT axons and CRH-containing neurons in the PVH (Liposits et al., 1987), and 5-HT compounds stimulate PVH CRHexpressing neurons (Gibbs and Vale, 1983; Brady et al., 1991; Hu et al., 1992; Laflamme et al., 1996; Javed et al., 1999; Jorgensen et al., 2002). Despite these findings, the relative importance of central 5-HT circuits and the involvement of specific 5-HTRs in HPA axis function remain unclear. Contributing to this uncertainty is the limited subtype specificity of the available 5-HTR agonists. These compounds have significant affinities for multiple 5-HTRs, which has complicated attempts to define the role of 5-HT and specific 5-HTRs in the regulation of the HPA axis via action at $\mathrm{CRH}$ neurons.

To clarify mechanisms underlying 5-HT-mediated activation of the HPA axis, we have established that the $5-\mathrm{HT}_{2 \mathrm{C}} \mathrm{R}$ is the predominant 5-HTR subtype expressed in the PVH, that $5-\mathrm{HT}_{2 \mathrm{C}} \mathrm{R}$ agonists and antagonists regulate $\mathrm{CRH}$ activity, and that genetic inactivation of $5-\mathrm{HT}_{2 \mathrm{C}}$ Rs perturbs serotonergic regulation of the HPA axis. Altogether, these studies delineate a mechanism through which central 5-HT systems regulate neuroendocrine responses potentially relevant to a variety of neuropsychiatric disorders.

\section{Materials and Methods}

Animals. Adult male C57BL/6 mice [2-3 months old; The Jackson Laboratory (Bar Harbor, ME), Charles River (Wilmington, MA), or CLEA (Tokyo, Japan)], hemizygous mice bearing a null mutation of the $\mathrm{X}$-linked $h$ tr2c gene $\left(5-\mathrm{HT}_{2 \mathrm{C}} \mathrm{R}\right.$ knock-out) congenic on a C57BL/6J background and age-matched wild-type littermates (2-4 months old) (Tecott et al., 1995), and Sprague Dawley rats [2-3 months old; Taconic Farms (Germantown, NY) or The Jackson Laboratory] were used. Rodents had water and laboratory chow pellets available ad libitum in a light $(12 \mathrm{~h}$ on/12 h off) and temperature-controlled environment $\left(21.5-22.5^{\circ} \mathrm{C}\right)$. All procedures used were approved by institutional Animal Care and Use committees or the United Kingdom Home Office.

Neurohistochemical studies. Four experimental groups were used: (1) C57BL/6 mice treated at the onset of the light cycle with pyrogen-free $0.9 \%$ saline or the high-affinity $5-\mathrm{HT}_{2 \mathrm{C}} \mathrm{R}$ agonist m-chlorophenylpiperazine (mCPP) $(2.5$ or $5.0 \mathrm{mg} / \mathrm{kg}$, i.p.; $n=3-4$ per dose); (2) rats fitted with a catheter in the femoral vein as described previously (Elmquist et al., 1996; Elias et al., 1998) 5-7 d before treatment with saline, $\mathrm{mCPP}(0.5,2.5$, or $5.0 \mathrm{mg} / \mathrm{kg}$, i.v. $)$, or the 5 -HT reuptake inhibitor/5-HT-stimulated release compound D-fenfluramine (D-fen; $0.1,1.0$, or $2.0 \mathrm{mg} / \mathrm{kg}$, i.v.) at the onset of the light cycle $(n=3-5$ per dose); (3) rats treated during the light cycle with $40 \mu \mathrm{g}$ of colchicine (Sigma-Aldrich, St. Louis, MO) in $10 \mu$ l of pyrogen-free $0.9 \%$ saline infused into the lateral ventricle to enhance CRH visualization $(n=5)$; and (4) untreated 5- $\mathrm{HT}_{2 \mathrm{C}} \mathrm{R}$ knock-out and wild-type mice perfused during the light cycle for hypothalamic neuropeptide expression analysis ( $n=8-9$ per genotype). Using methods standard in our laboratory (Elmquist et al., 1996; Elias et al., 1998; Liu et al., 2003; Heisler et al., 2006), brain tissue was prepared through transcardial perfusion with $0.9 \%$ saline and then $10 \%$ neutral buffered formalin (Sigma-Aldrich) under chloral hydrate anesthesia ( $350 \mathrm{mg} / \mathrm{kg}$, i.p.) $2 \mathrm{~h}$ after saline, $\mathrm{mCPP}$, or D-fen treatment and 36-48 h after colchicine treatment. Brains were postfixed and sectioned coronally at a thickness of 25-30 $\mu \mathrm{M}$ on a freezing sliding microtome.

Brain tissue was processed for single-label free-floating in situ hybridization histochemistry (ISHH), single-label immunohistochemistry (IHC) (Elmquist et al., 1996; Elias et al., 1998; Heisler et al., 2002; Liu et al., 2003; Yamamoto et al., 2003), or dual-label ISHH and IHC using methods detailed previously (Liu et al., 2003; Heisler et al., 2006). ISHH was performed using an antisense ${ }^{35}$ S-labeled CRH (Liu et al., 2003),
${ }^{35}$ S-labeled 5-HT $2 \mathrm{C}$ (Molineaux et al., 1989), ${ }^{35}$ S-labeled cocaine- and amphetamine-regulated transcript (CART) (Couceyro et al., 1997), ${ }^{35} \mathrm{~S}$ labeled pro-opiomelanocortin (POMC) (Cheung et al., 1997), or ${ }^{35} \mathrm{~S}$ labeled melanin-concentrating hormone $(\mathrm{MCH})(\mathrm{Qu}$ et al., 1996) riboprobe generated from cDNA templates by in vitro transcription with a $\mathrm{T} 3$ $\left(5-\mathrm{HT}_{2 \mathrm{C}} \mathrm{R}\right.$ and CART), T7 (CRH), or SP6 (POMC and MCH) polymerase, according to the manufacturer's protocol (Promega, Madison, WI). Sections processed for single-label ISHH were then mounted onto SuperFrost slides (Fisher Scientific, Hampton, NH), exposed to Biomax MR film (Kodak, Rochester, NY), and then dipped in NTB 2 photographic emulsion (Kodak). After 0.5-4 weeks, slides were developed with Kodak Fixer and D-19 Developer (Kodak). Dual-label ISHH and IHC or single-label IHC sections were processed using c-fos rabbit primary antiserum (Ab-5; 1:50,000; Oncogene, San Diego, CA) or rabbit CRH primary antiserum (1:10,000; Phoenix Pharmaceuticals, Belmont, CA) and biotinylated donkey anti-rabbit IgG secondary antibody (1:1000; Jackson ImmunoResearch, West Grove, PA) in PBS and $0.25 \%$ Triton X (Sigma-Aldrich).

Single and dual labeling was assessed throughout the rostral-caudal axis of the $\mathrm{PVH}$, the arcuate nucleus of the hypothalamus (ARC) for POMC mRNA analysis, or the lateral hypothalamic area (LHA) for $\mathrm{MCH}$ mRNA analysis (Paxinos and Franklin, 2001). For single-label IHC analysis, a threshold of size and intensity of immunoreactive-positive neurons was set. For dual-label analysis, clusters of grains of ${ }^{35} \mathrm{~S}$-labeled $\mathrm{CRH}$ overlying c-fos immunoreactivity (FOS-IR)-positive neurons or ${ }^{35} \mathrm{~S}$-labeled $5-\mathrm{HT}_{2 \mathrm{C}} \mathrm{R}$ grains overlying CRH-IR cell bodies that were three times greater than background hybridization levels and conformed to the immunoreactive cell body were counted as coexpressed. Basal CRH, CART, POMC, and MCH mRNA expression in 5- $\mathrm{HT}_{2 \mathrm{C}} \mathrm{R}$ knock-out and wild-type mice was examined in adjacent sections of brain tissue by determining the intensity of autoradiographic images of the ${ }^{35} \mathrm{~S}$-labeled neuropeptides on Biomax MR film as measured with a light box, a digital camera interface, and NIH Image software. $\mathrm{PVH}^{35} \mathrm{~S}$-labeled CRH, PVH ${ }^{35}$ S-labeled CART, ARC ${ }^{35}$ S-labeled POMC, and LHA ${ }^{35}$ S-labeled MCH signal density was analyzed by computing the integrated density (the sum of the gray values minus background). This was performed in four sections in PVH $(0.70,0.82,0.94$, and $1.06 \mathrm{~mm}$ caudal to bregma), ARC $(1.46,1.70,1.94$, and $2.18 \mathrm{~mm}$ caudal to bregma), or LHA $(1.22,1.58$, 1.94 , and $2.18 \mathrm{~mm}$ caudal to bregma), and the average integrated density of neuropeptide hybridization signal was calculated.

Laser-capture microdissection and Affymetrix GeneChip analysis. C57BL/6 mice $(n=3)$ were rapidly decapitated, and brains were extracted, snap frozen, and sectioned coronally at a thickness of $14 \mu \mathrm{m}$ on a cryostat. Brain sections were mounted onto RNase-free membranecoated glass slides (PALM MembraneSlides; P.A.L.M. Microlaser Technologies, Bernried, Germany), fixed in 95\% ethanol, rehydrated in 75 and $50 \%$ ethanol, stained with $1 \%$ cresyl violet, dehydrated in a graded ethanol series, and immersed in Histoclear. The extent of the PVH (0.70$1.22 \mathrm{~mm}$ caudal to bregma, yielding $\sim 35$ sections) was microdissected using a PALM Microlaser System (P.A.L.M. Microlaser Technologies). Total RNA was isolated (typical yield, $20 \mathrm{ng}$ ) in accord with the manufacturer's protocol (RNAqueous-Micro Kit; Ambion, Austin, TX). RNA was amplified and biotin labeled using two cycles of in vitro transcription (GeneChip IVT labeling kit; Affymetrix, Santa Clara, CA) before hybridization onto Affymetrix Murine Expression Arrays 4302.0 using an Affymetrix fluidics station according to the manufacturer's protocol. Chips were scanned using an Affymetrix GS3000 scanner, and data were extracted using Affymetrix GCOS software. Downstream analysis was performed using GeneSpring 7.2 (Agilent Technologies, Palo Alto, CA). Data regarding the presence/absence and normalized expression values for transcripts of 135 -HTR genes in the PVH were obtained.

Real-time quantitative PCR. C57BL/6 mice ( $n=4-5$ per treatment) were pretreated with $0.9 \%$ saline or the selective blood-brain barrierpenetrating $5-\mathrm{HT}_{2 \mathrm{C}} \mathrm{R}$ antagonist SB242084 dihydrochloride $(1.0 \mathrm{mg} / \mathrm{kg}$, i.p.) (Kennet et al., 1997) and 30 min later were treated with $0.9 \%$ saline or D-fen $(3.0 \mathrm{mg} / \mathrm{kg}$, i.p.). Sixty minutes after this, mice were decapitated, and the hypothalamus was removed for RNA extraction using methods described previously (Nonogaki et al., 2006). Briefly, total RNA was isolated using the RNeasy Midi kit (Qiagen, Hilden, Germany) according to 
the manufacturer's directions, and cDNA synthesis was performed using a Super Script III First-Strand Synthesis System for reverse transcription (RT)-PCR kit (Invitrogen, Rockville, MD) using $1 \mu \mathrm{g}$ of total RNA. cDNA synthesized from total RNA was evaluated in a real-time PCR quantitative system (Light Cycler Quick System 350S; Roche Diagnostics, Mannheim, Germany). The primers used were mouse CRH (sense, 5'-CCG GGC AGA GCA GTT AGC-3'; antisense, 5'-CAA CAT TTC ATT TCC CGA TAA TCT C- $3^{\prime}$ ) and mouse $\beta$-actin (sense, $5^{\prime}$-TTG TAA CCA ACT GGG ACG ATA TGG-3'; antisense, 5' -GAT CTT GAT CTT CAT GGT GCT AGG-3'). The relative amount of mRNA was calculated with $\beta$-actin mRNA as the invariant control. The data are presented as percentage change of the mean value of the saline-treated control group.

Electrophysiology studies. Using standard electrophysiological methods (Cowley et al., 1999a; Pronchuk et al., 2002), recordings in the presence of mCPP (4-6 $\mu \mathrm{M})$, a control solution, and/or RS102221 (500 nM to 1 $\mu \mathrm{M})$ were made from 35 medial parvocellular PVH (mpPVH) neurons from $250 \mu \mathrm{m}$ coronal brain slices of male Sprague Dawley rats. Briefly, glass patch micropipettes (5-7 M $\Omega$ ) were filled with pipette solution for perforated-patch recordings (Cowley et al., 2003). Once stable perforated-patch recording conditions were established, $\mathrm{GABA}_{\mathrm{A}}$ receptormediated synaptic responses were evoked with the cell held in voltage clamp at $-40 \mathrm{mV}$. Membrane potential was assessed in current clamp. Neurons served as their own controls; drugs were applied and washed out via bath perfusion (Cowley et al., 1999b, 2003). After this, Neurobiotin was electroporated into the cell, and the slice tissue was fixed overnight in a $4 \%$ paraformaldehyde in PBS solution at $4^{\circ} \mathrm{C}$ and dehydrated overnight at $4^{\circ} \mathrm{C}$ in $20 \%$ sucrose in PBS. Tissue was then cut $(25 \mu \mathrm{m})$ with a cryostat (Jung Frigocut 2800E; Leica Microsystems, Bannockburn, IL) and processed for IHC for CRH (1:3000; Peninsula Laboratories, Belmont, CA) and thyrotropin-releasing hormone (TRH; 1:3000; Dr. Eduardo Nillni, Brown University, Providence, RI).

$C R H$ ex vivo release. $\mathrm{CRH}$ release was measured in $5-\mathrm{HT}_{2 \mathrm{C}} \mathrm{R}$ knockout and wild-type mice ( $n=29$ per genotype) $3-4 \mathrm{~h}$ after the onset of the light cycle using methods described previously (Raber and Bloom, 1994; Raber et al., 1995). Briefly, a $1.5 \mathrm{~mm}$ coronal section of the hypothalamus beginning $0.7 \mathrm{~mm}$ caudal to bregma was dissected and placed onto a Brinkmann (Westbury, NY) tissue chopper for the preparation of 300 $\mu \mathrm{m}$ slices. Slices representing one entire hypothalamus were placed into individual chambers and superfused using an in vitro superfusion system (Brandel, Gaithersburg, MD). CRH release was determined 100 min later for a basal CRH measure and in 15 min intervals (collections 1 and 2) after mCPP $(1 \mu \mathrm{M}), 1$-(2,5-dimethoxy-4-iodophenyl)-2-aminopropane hydrochloride (DOI) (10 $\mu \mathrm{M}$ ), 8-hydroxy-2-(dipropylamino)tetralin (8OH-DPAT) $(1 \mu \mathrm{M})$, or D-fen $(1 \mu \mathrm{M})$ infusion. To confirm tissue viability at the end of the experiment, slices were exposed to $\mathrm{KCl}(60 \mathrm{~mm})$ for 30 min; data from any tissue that did not increase release at least $50 \%$ over baseline were discarded. The concentration of CRH in the superfusates was determined by radioimmunoassay (RIA) as described previously (Raber and Bloom, 1994; Raber et al., 1995).

CORT RIA. Plasma CORT was measured in $5-\mathrm{HT}_{2 \mathrm{C}} \mathrm{R}$ knock-out and wild-type mice both basally and after mCPP or D-fen $(n=6-10$ per genotype and treatment). Specifically, basal CORT was assessed $1 \mathrm{~h}$ after the onset of the light and dark cycle in untreated mice using a rat corticosterone RIA kit according to the manufacturer's protocol (MP Biomedicals, Irvine, CA). In another group of mice, plasma CORT was assessed $1 \mathrm{~h}$ after treatment with saline, $\mathrm{mCPP}(2.5$ or $5.0 \mathrm{mg} / \mathrm{kg}$, i.p. $)$, or D-fen $(3.0 \mathrm{mg} / \mathrm{kg}$, i.p.), which were administered $2-4 \mathrm{~h}$ after the onset of the light cycle.

Drugs. The high-affinity $5-\mathrm{HT}_{2 \mathrm{C}} \mathrm{R}$ agonists mCPP (Sigma-Aldrich) and DOI (Sigma-Aldrich), the high-affinity $5-\mathrm{HT}_{1} \mathrm{R}$ agonist $8-\mathrm{OH}-$ DPAT (Sigma-Aldrich), and the 5-HT reuptake inhibitor/5-HT release stimulator D-fen (Sigma-Aldrich) were dissolved in $0.9 \%$ sterile saline and administered either intraperitoneally or intravenously for in vivo studies. The $5-\mathrm{HT}_{2 \mathrm{C}} \mathrm{R}$ antagonist SB242084 dihydrochloride (SigmaAldrich) was prepared as a stock solution by dissolving $5.0 \mathrm{mg}$ in $1.0 \mathrm{ml}$ of distilled water. Immediately before use, $0.1 \mathrm{ml}$ of this stock solution was suspended in $4.9 \mathrm{ml}$ of $0.9 \%$ sterile saline. For electrophysiological experiments, $\mathrm{mCPP}$ was prepared as $100 \mu \mathrm{M}$ stock solution in distilled water and diluted to a final concentration of between 2 and $6 \mu \mathrm{M}$ imme- diately before use; the high-affinity $5-\mathrm{HT}_{2 \mathrm{C}} \mathrm{R}$ antagonist $\mathrm{RS} 102221$ (Tocris Bioscience, Ellisville, $\mathrm{MO}$ ) was prepared as a stock solution of $10 \mathrm{mM}$ and diluted to $500 \mathrm{~nm}$ in artificial CSF immediately before use.

Data analysis. Before performing statistical tests, data were assessed for normality with a Shapiro-Wilk's test to determine whether parametric or nonparametric tests were warranted using SPSS PC (Chicago, IL) Advanced Statistics (version 11.5) software. Neurohistochemical, endocrine, and behavioral data were analyzed with ANOVA followed by Tukey's post hoc comparisons, independent-samples $t$ tests, or paired $t$ tests. Electrophysiological data and hypothalamic CRH release data were analyzed with paired $t$ tests. For all analyses, significance was assigned at $p \leq 0.05$.

\section{Results}

\section{5-HT agonists activate PVH CRH-containing neurons in vivo}

We hypothesized that 5-HT-induced CORT release is predominantly achieved via action at $\mathrm{CRH}$-containing neurons in the PVH. The most commonly used 5-HT compounds enhancing CORT release are mCPP and fenfluramine (Fuller and Snoddy, 1980, 1990; Sevy et al., 1994; Silverstone et al., 1994; Broocks et al., 2000; Vielhaber et al., 2005). In addition to $5-\mathrm{HT}_{2 \mathrm{C}} \mathrm{Rs}, \mathrm{mCPP}$ also has high binding affinity for the $5-\mathrm{HT}_{2 \mathrm{~A}} \mathrm{R}, 5-\mathrm{HT}_{1 \mathrm{~A}} \mathrm{R}, 5-\mathrm{HT}_{1 \mathrm{~B}} \mathrm{R}$, and $5-\mathrm{HT}_{3} \mathrm{R}$ subtypes (Koe et al., 1992). We investigated whether $\mathrm{mCPP}$ or $\mathrm{D}$-fen activate PVH neurons in vivo using FOS-IR as a marker of neuronal activation. Consistent with previous reports, we observed that both $\mathrm{mCPP}(2.5$ or $5.0 \mathrm{mg} / \mathrm{kg}$, i.v.) and D-fen ( 1.0 or $2.0 \mathrm{mg} / \mathrm{kg}$, i.v.) induced robust and dose-related increases in total FOS-IR expression compared with saline $(p<0.001 ; n=$ $4-5$ per dose) in the rat PVH (Li and Rowland, 1993; Singewald et al., 2003).

Previous reports indicate that DL-fen $(25.0 \mathrm{mg} / \mathrm{kg}$, i.p. $)$ and D-fen $(5.0-10.0 \mathrm{mg} / \mathrm{kg}$, i.p.) induce c-fos in CRH-IR perikarya in the rat PVH (Richard et al., 1992; Laflamme et al., 1996; Javed et al., 1999). Using adjacent sections of brain tissue from rats treated with saline (Fig. 1a), mCPP $(2.5 \mathrm{mg} / \mathrm{kg}$, i.v.) (Fig. $1 b)$, or D-fen $(1.0 \mathrm{mg} / \mathrm{kg}$, i.v.), we next examined whether these compounds increase FOS in CRH mRNA-containing cells ( $n=4-5$ per dose). Using IHC to identify FOS-IR-positive cells and ISHH to label CRH mRNA-containing neurons (Fig. 1c), we observed that $\mathrm{mCPP}$ induced FOS-IR in $72 \pm 5 \%$ of ${ }^{35} \mathrm{~S}$-labeled $\mathrm{CRH}-$ expressing neurons (Fig. $1 d, e$ ), and D-fen induced FOS-IR in $88 \pm 1 \%$ of ${ }^{35} \mathrm{~S}$-labeled CRH-expressing neurons, whereas saline induced FOS-IR in only $14 \pm 1 \%$ of ${ }^{35} \mathrm{~S}$-labeled CRH-expressing neurons. Therefore, the 5-HT compounds were highly effective in inducing FOS-IR in CRH neurons. Conversely, not all FOS-IR neurons were positive for CRH. As may be noted in Figure $1 d$, approximately one-half of FOS-IR-positive neurons (mCPP, $57 \pm 3 \%$; D-fen, $55 \pm 2 \%$ ) did not meet the criteria for coexpression with CRH-containing neurons. This is comparable with the expression rate observed after saline treatment $(43 \pm 2 \%)$. Together, these findings indicate that 5-HT compounds substantially activate PVH CRH neurons and suggest that 5-HT compounds (and saline) also activate non-CRH-containing $\mathrm{PVH}$ neurons in vivo.

\section{PVH CRH-containing neurons express $5-\mathrm{HT}_{2 \mathrm{C}} \mathrm{Rs}$}

We hypothesized that 5-HT directly activates $\mathrm{CRH}$-containing neurons via action at 5-HTRs expressed by these cells. To investigate which 5-HTRs are expressed in the PVH, we used lasercapture microdissection to remove the rostral-caudal extent of the PVH. We compared levels of 5-HTR expression in the PVH using Affymetrix 430 2.0 Murine Expression Arrays. Probe sets representing $5-\mathrm{HT}_{1 \mathrm{~A}} \mathrm{Rs}, 5-\mathrm{HT}_{1 \mathrm{~B}} \mathrm{Rs}, 5-\mathrm{HT}_{1 \mathrm{D}} \mathrm{Rs}, 5-\mathrm{HT}_{1 \mathrm{~F}} \mathrm{Rs}$, 5- $\mathrm{HT}_{2 \mathrm{~B}} \mathrm{Rs}, 5-\mathrm{HT}_{2 \mathrm{C}} \mathrm{Rs}, 5-\mathrm{HT}_{3 \mathrm{~A}} \mathrm{Rs}, 5-\mathrm{HT}_{3 \mathrm{~B}} \mathrm{Rs}, 5-\mathrm{HT}_{4} \mathrm{Rs}, 5-\mathrm{HT}_{5 \mathrm{~A}} \mathrm{Rs}$, 


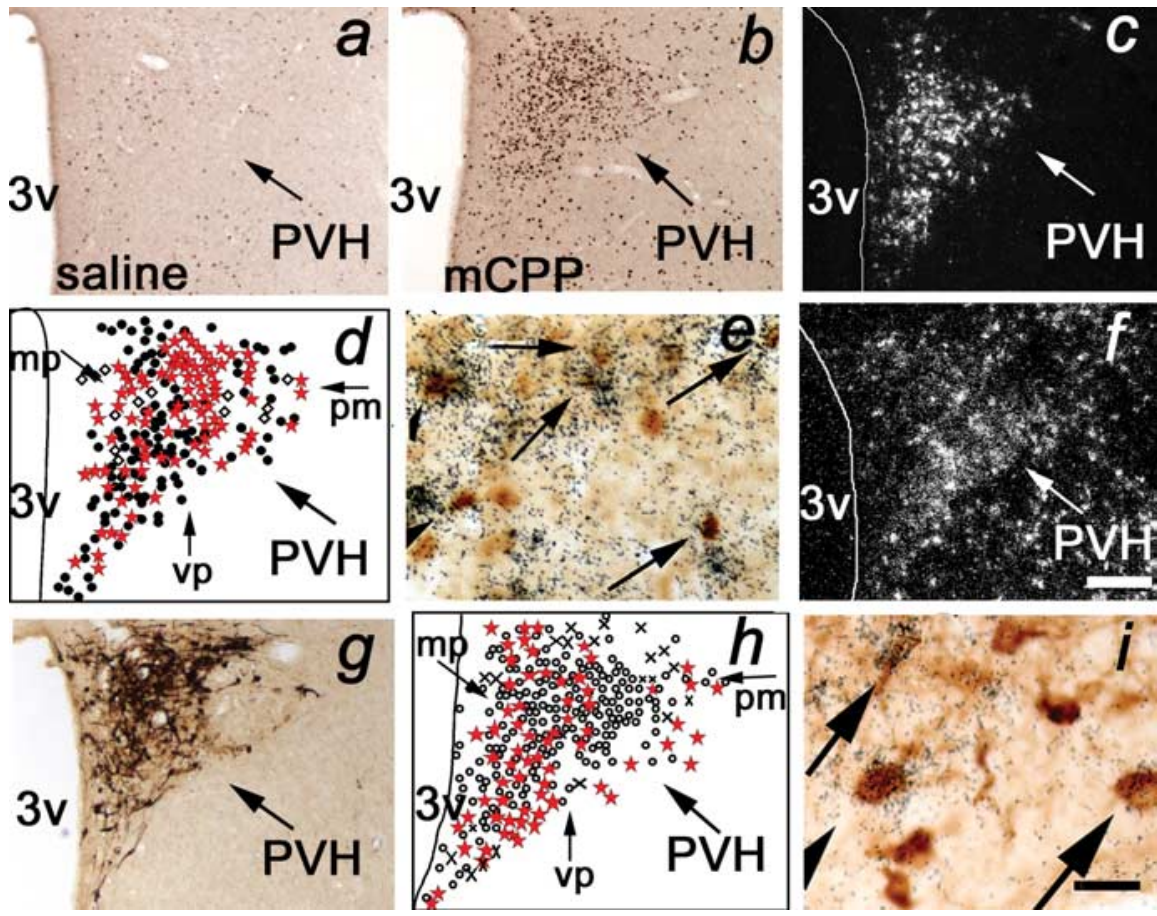

Figure 1. $\mathrm{m}(\mathrm{PP}$ and $\mathrm{D}$-fen activated PVH CRH-containing neurons expressing 5-HT 2 Rs in vivo. $\boldsymbol{a}, \boldsymbol{b}$, Compared with saline ( $\boldsymbol{a}$ ), $\mathrm{mCPP}(\boldsymbol{b} ; 2.5 \mathrm{mg} / \mathrm{kg}$, i.v.) induced a significant increase in FOS-IR (brown nuclear stain) in parvocellular PVH neurons. $\boldsymbol{c}-\boldsymbol{e}$, $\mathrm{mCPP}$ induced FOS-IR in PVH CRH mRNA-containing neurons. c, CRH mRNA (cluster of white grains) is expressed in parvocellular PVH neurons. $\boldsymbol{d}$, Schematic representation of PVH CRH mRNA and FOS-IR coexpression. Open diamonds, CRH mRNA; filled circles, FOS-IR; red stars, coexpression of CRH mRNA and FOS-IR. $\boldsymbol{e}$, Arrows identify coexpression of CRH mRNA (cluster of black grains) and FOS-IR (brown nuclear stain). $\boldsymbol{f}, 5-\mathrm{HT}_{2} \mathrm{R}$ mRNA (cluster of white grains) is expressed in parvocellular PVH neurons. $\boldsymbol{g}-\boldsymbol{i}, 5-\mathrm{HT}_{2} \mathrm{R}$ mRNA is coexpressed with PVH CRH-IR-containing neurons. $\boldsymbol{g}$, PVH CRH-IR (brown cytoplasm stain) expression. $\boldsymbol{h}$, Schematic of PVH 5- $\mathrm{HT}_{2 \mathrm{C}} \mathrm{R}$ mRNA and CRH-IR coexpression. Circles, CRH-IR; crosses, 5- $\mathrm{HT}_{2 \mathrm{C}} \mathrm{R}$ mRNA; red stars, coexpression of CRH-IR and $5-\mathrm{HT}_{2} \mathrm{R}$ mRNA. $\boldsymbol{i}$, Arrows identify coexpression of $5-\mathrm{HT}_{2} \mathrm{R}$ mRNA (cluster of black grains) and CRH-IR (brown cytoplasm stain). 3v, Third ventricle; $\mathrm{mp}$, medial parvocellular division; $\mathrm{pm}$, posterior magnocellular division; $\mathrm{vp}$, ventral parvocellular division. Scale bars: (in $\boldsymbol{f}$ ) $\boldsymbol{a}-\boldsymbol{d}, \boldsymbol{f}-\boldsymbol{h}, 200 \mu \mathrm{m}$; (in $\boldsymbol{f}) \boldsymbol{e}, 20 \mu \mathrm{m} ; \boldsymbol{i}, 30 \mu \mathrm{m}$.

$5-\mathrm{HT}_{5 \mathrm{~B}} \mathrm{Rs}, 5-\mathrm{HT}_{6} \mathrm{Rs}$, and $5-\mathrm{HT}_{7} \mathrm{Rs}$ were present on the array. Of these, the $\mathrm{G}_{\mathrm{i}}$-coupled 5- $\mathrm{HT}_{1 \mathrm{D}} \mathrm{R}$ (Htr1d BB829587; expression level mean \pm SEM, $60 \pm 16.0)$ and $\mathrm{G}_{\mathrm{q}}$-coupled 5- $\mathrm{HT}_{2 \mathrm{C}} \mathrm{R}(\mathrm{Htr} 2 \mathrm{c}$ BQ174268; expression level mean \pm SEM, $340 \pm 37.8$ ) were most highly expressed and were the only 5 -HTRs consistently identified as present in the PVH of mice $(n=3)$. If 5 -HT directly activates $\mathrm{CRH}$-containing neurons to affect the HPA axis, as we hypothesize, then these data suggest that the $5-\mathrm{HT}_{2 \mathrm{C}} \mathrm{R}$ is a strong candidate receptor through which this effect may be achieved. This would be consistent with the MCPP and D-fen PVH-induced FOS-IR data described above; both $\mathrm{MCPP}$ and the metabolite of D-fen, norfenfluramine, have high binding affinity for $5-\mathrm{HT}_{2 \mathrm{C}} \mathrm{Rs}$ (Porter et al., 1999).

$5-\mathrm{HT}_{2 \mathrm{C}} \mathrm{Rs}$ are widely expressed in the rodent brain (Molineaux et al., 1989). We further assessed the distribution pattern and chemical phenotype of PVH $5-\mathrm{HT}_{2 \mathrm{C}} \mathrm{R}$-expressing neurons in the rat using ISHH with a ${ }^{35} \mathrm{~S}$-labeled $5-\mathrm{HT}_{2 \mathrm{C}} \mathrm{R}$ riboprobe applied to the hypothalamus. $5-\mathrm{HT}_{2 \mathrm{C}} \mathrm{R}$ mRNA $(n=5)$ (Fig. $\left.1 f\right)$ is diffusely expressed in the parvocellular PVH, where CRHcontaining neurons reside (Fig. $1 c, g$ ). Using dual-labeling techniques, we observed that $48 \pm 9 \%$ of total PVH CRH-IR neurons express ${ }^{35} \mathrm{~S}$-labeled $5-\mathrm{HT}_{2 \mathrm{C}} \mathrm{R}$ mRNA $(n=5)$ (Fig. $\left.1 h, i\right)$. These findings were consistent throughout the rostral-caudal extent of the $\mathrm{PVH}$ and suggest that $5-\mathrm{HT}_{2 \mathrm{C}} \mathrm{Rs}$ are positioned to regulate $\mathrm{PVH}$ CRH-containing neurons.

\section{5-HT agonist activates $\mathrm{PVH}$}

CRH-containing neurons

Using electrophysiological techniques, we next recorded from neurons in coronal rat hypothalamic slices containing the $\mathrm{mp}$ $\mathrm{PVH}$ in the presence of the high-affinity $5-\mathrm{HT}_{2 \mathrm{C}} \mathrm{R}$ agonist $\mathrm{mCPP}$ to assess the direct effect of this compound on $\mathrm{CRH}$ activity $(n=35)$. Using a perforated-patch version of whole-cell intracellular recording technique (Cowley et al., 1999b; Pronchuk et al., 2002), we observed that MCPP (4-6 $\mu \mathrm{M})$ depolarized and induced more than a twofold increase in spontaneous firing rates in five of 14 neurons; an effect reversed by drug washout (Fig. $2 a-c$ ). Nine neurons did not respond to $\mathrm{mCPP}$ (data not shown). These $14 \mathrm{mpPVH}$ neurons were subsequently stained for the presence of biocytin and CRH. Figure $2 d$ illustrates a multipolar CRH-positive, $\mathrm{mCPP}$-sensitive neuron in mpPVH. We observed that $100 \%$ (five of the five) of neurons that responded to $\mathrm{mCPP}$ were CRH-positive, and $100 \%$ of the neurons that did not respond to $\mathrm{mCPP}$ (nine of nine) were not.

We next examined whether the effects of mCPP on CRH neuronal activity could be blocked with a $5-\mathrm{HT}_{2 \mathrm{C}} \mathrm{R}$ antagonist. The 5- $\mathrm{HT}_{2 \mathrm{C}} \mathrm{R}$ antagonist RS102221 (500 $\mathrm{nM}$ to $1 \mu \mathrm{M}$ ) did not induce alterations in membrane potential compared with control treatment (mean \pm SEM control $=$ $-60.4 \pm 3.5, n=5 ; \operatorname{RS} 102221=$ $-54.60 \pm 2.9, n=5$ ), whereas mCPP produced a significant depolarization compared with control in four of six mpPVH cells (Fig. 2e). RS102221 attenuated mCPP-induced depolarization in five of five cells (Fig. 2e). Together, these data suggest that $5-\mathrm{HT}_{2 \mathrm{C}} \mathrm{R}$ stimulation activates $\mathrm{PVH} \mathrm{CRH}$ neurons.

5-HT agonists require $5-\mathrm{HT}_{2 \mathrm{C}}$ Rs to stimulate $\mathrm{CRH}$ release and regulate CRH mRNA

To examine whether 5-HT-induced activation of CRH neurons also impacts on $\mathrm{CRH}$ release via action at $5-\mathrm{HT}_{2 \mathrm{C}} \mathrm{Rs}$, hypothalamic slices containing the $\mathrm{PVH}$ from $5-\mathrm{HT}_{2 \mathrm{C}} \mathrm{R}$ knock-out and wild-type mice were superfused with $\mathrm{mCPP}(1.0 \mu \mathrm{M})$, DOI (10.0 $\mu \mathrm{M})$, or 8 -OH-DPAT $(1.0 \mu \mathrm{M})(n=19$ per genotype). Despite no differences in basal CRH release, fractions collected after drug administration revealed significant phenotypic differences in $\mathrm{CRH}$ release in response to $\mathrm{mCPP}, \mathrm{DOI}$, and 8-OH-DPAT. Specifically, mCPP (Fig. $3 a)(p<0.05)$, DOI (Fig. $3 a)(p<0.01)$, and 8 -OH-DPAT (Fig. $3 a)(p<0.001)$ significantly increased the percentage of CRH release in wild-type mice. Supporting the notion that the complete effect of 5-HT agonist-induced CRH release requires functional $5-\mathrm{HT}_{2 \mathrm{C}} \mathrm{Rs}$, these compounds were ineffective in enhancing the percentage of $\mathrm{CRH}$ release in 5- $\mathrm{HT}_{2 \mathrm{C}} \mathrm{R}$-deficient mice (Fig. $3 b$ ).

We next investigated the effect of D-fen $(1.0 \mu \mathrm{M} ; n=10$ per genotype) on CRH release. D-Fen stimulates the release of endogenous 5-HT and blocks its reuptake, thereby facilitating 5-HT action at all receptors. This provides a more physiologically rele- 
a
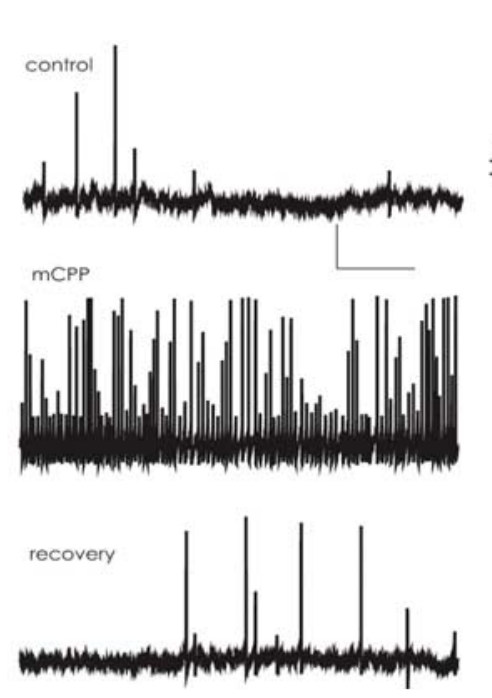
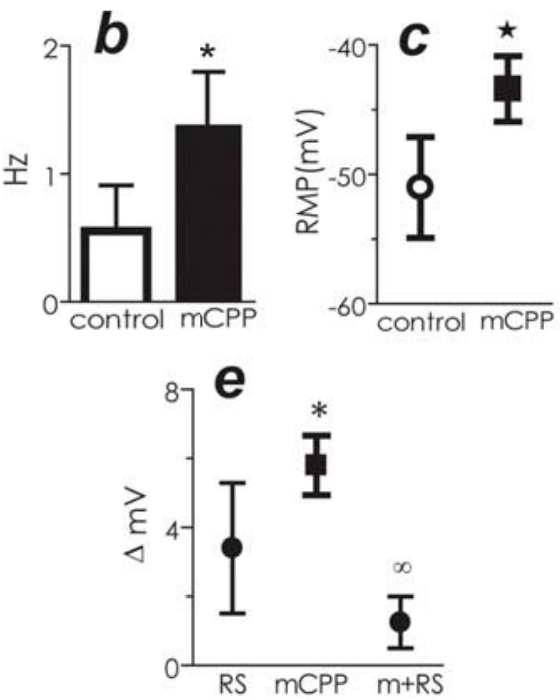

d

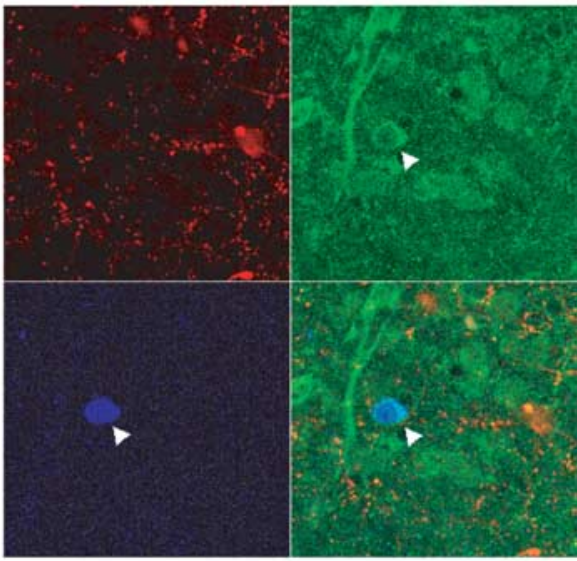

Figure 2. $\quad \mathrm{mCPP}$ depolarized and increased the firing rate of CRH-containing neurons in the PVH. $\boldsymbol{a}$, mCPP depolarized mpPVH neurons. Membrane potential of mpPVH neuron recorded in control saline (top), in the presence of mCPP (middle), and after a 15 min washout (bottom). Calibration bars: $20 \mathrm{mV}, 10 \mathrm{~s}$. $\boldsymbol{b}$, mCPP increased the firing rate of mpPVH (RH-containing neurons compared with control conditions. c, mCPP depolarized mpPVH CRH-containing neurons compared with control conditions. RMP, Resting membrane potential. $\boldsymbol{d}$, Confirmation that recordings were made from CRH-containing neurons (arrowhead indicates recorded cell). Top left, TRH immunoreactivity; top right, CRH immunoreactivity; bottom left, biocytin histochemistry; bottom right, three images merged. e, 5-HT 2 R antagonist RS102221 (RS) did not significantly change membrane potential compared with control. In contrast, mCPP significantly changed membrane potential, and this effect was blocked by treatment with RS. Data are expressed as mean \pm SEM. ${ }^{*} p<0.05$ compared with control; ${ }^{\infty} p<0.05$ compared with mCPP.

a

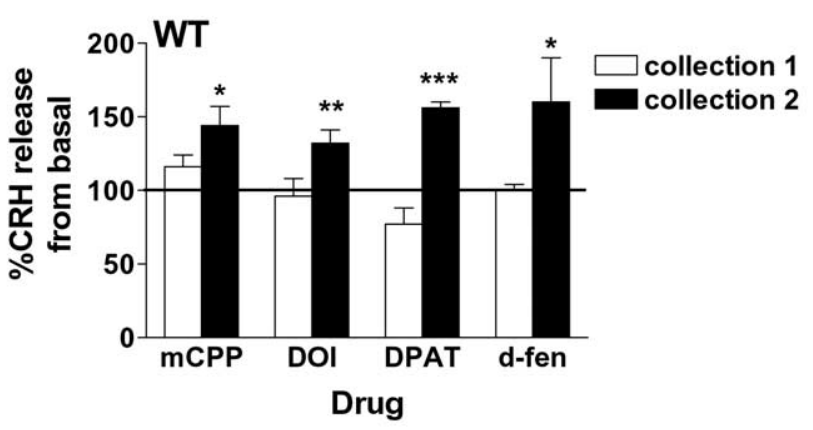

b

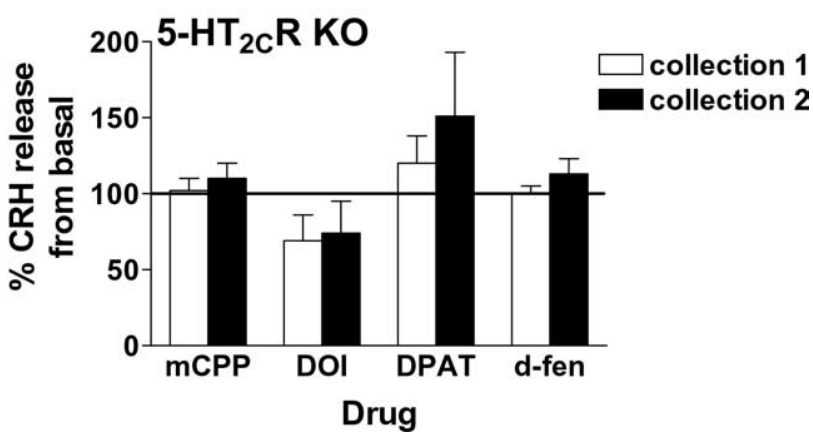

Figure 3. Genetic 5- $\mathrm{HT}_{2} \mathrm{R}$ inactivation abolished 5-HT compound-stimulated CRH release. $\boldsymbol{a}, \boldsymbol{b}, \mathrm{mCPP}(1.0 \mu \mathrm{M}), \mathrm{DOI}(10.0 \mu \mathrm{M}), 8-0 \mathrm{H}-\mathrm{DPAT}(1.0 \mu \mathrm{M})$, and D-fen $(1.0 \mu \mathrm{m})$ stimulated the in vitro release of $\mathrm{CRH} 15-45$ min after drug infusion (black bars; collection 2 ) in wild-type mice (WT; $\boldsymbol{a})$ but not $5-\mathrm{HT}_{2} \mathrm{R}$ knock-out littermates $\left(5-\mathrm{HT}_{2} \mathrm{R} \mathrm{KO} ; \boldsymbol{b}\right)$ relative to the basal collection period in hypothalamic extracts. Zero to fifteen minutes after drug infusion (white bars; collection 1), CRH release was not different from basal release in either genotype. Data are expressed as mean \pm SEM. ${ }^{*} p<0.05 ;{ }^{* *} p<0.01 ;{ }^{* * *} p<0.001$ compared with basal CRH release using paired $t$ test.

vant assessment of 5-HT-induced stimulation of $\mathrm{CRH}$ release than that obtained from 5-HT agonist treatment. We observed that D-fen significantly increased the percentage of CRH release in wild-type mice (Fig. $3 a)(p<0.05)$, but this effect was abol-

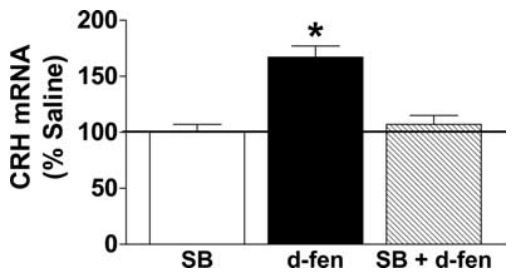

Figure 4. Pharmacological $5-\mathrm{HT}_{2} \mathrm{C}$ blockade abolished D-fen-induced enhancement of $\mathrm{CRH}$ mRNA expression. Acute treatment with the $5-\mathrm{HT}_{2}$ R antagonist SB242084 (SB; $1.0 \mathrm{mg} / \mathrm{kg}$, i.p.; white bar) produced no effect on (RH mRNA compared with $0.9 \%$ saline treatment. Relative to SB treatment, D-fen $(3.0 \mathrm{mg} / \mathrm{kg}$, i.p.; black bar) significantly increased the percentage of CRH mRNA expression in the hypothalamus as measured by real-time quantitative PCR, and pretreatment with $S B(1.0 \mathrm{mg} / \mathrm{kg}$, i.p.; striped bar) abolished this effect. Data are expressed as mean \pm SEM. ${ }^{*} p<0.05$, o-fen compared with all other conditions.

ished in $5-\mathrm{HT}_{2 \mathrm{C}} \mathrm{R}$ knock-out mice (Fig. $3 b$ ). These data provide compelling support for a critical role for $5-\mathrm{HT}_{2 \mathrm{C}} \mathrm{Rs}$ in 5 -HTinduced CRH release.

To extend these findings, we then examined whether D-fen alters CRH mRNA in vivo and whether acute pharmacological blockade of $5-\mathrm{HT}_{2 \mathrm{C}}$ Rs would attenuate this effect. C57BL/6 mice were pretreated with $0.9 \%$ saline or the $5-\mathrm{HT}_{2 \mathrm{C}} \mathrm{R}$ antagonist SB242084 (1.0 mg/kg, i.p.) and were treated with $0.9 \%$ saline or D-fen (3.0 mg/kg, i.p.) $30 \mathrm{~min}$ later ( $n=4-5$ per treatment). No differences were observed between SB242084 and 0.9\% saline treatment. However, relative to SB242084, D-fen significantly increased hypothalamic CRH mRNA expression, and pretreatment with SB242084 abolished this effect (Fig. 4) $(p<0.05)$. These findings demonstrate that acute $5-\mathrm{HT}_{2 \mathrm{C}} \mathrm{R}$ blockade is sufficient to render ineffective $\mathrm{D}$-fen-induced increased CRH mRNA.

If 5 -HT action at $5-\mathrm{HT}_{2 \mathrm{C}} \mathrm{Rs}$ is critical to $5-\mathrm{HT}$ regulation of $\mathrm{CRH}$ release, then it may be hypothesized that mice lacking functional $5-\mathrm{HT}_{2 \mathrm{C}}$ Rs will display a downregulation of CRH mRNA. We investigated this hypothesis by comparing basal CRH mRNA expression in $5-\mathrm{HT}_{2 \mathrm{C}} \mathrm{R}$-deficient and wild-type mice using ISHH ( $n=8-9$ per genotype). Densitometric analysis of CRH hybrid- 


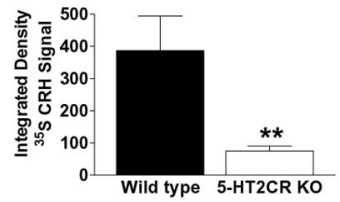

b

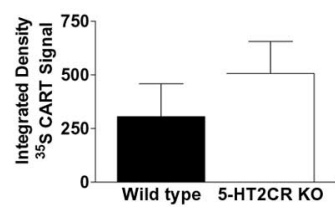

c

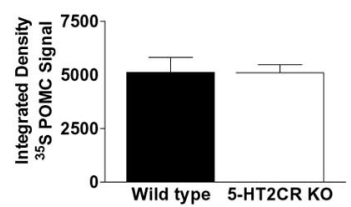

d

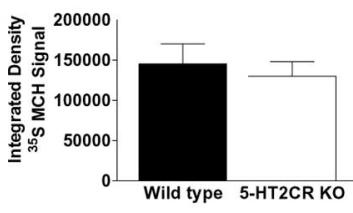

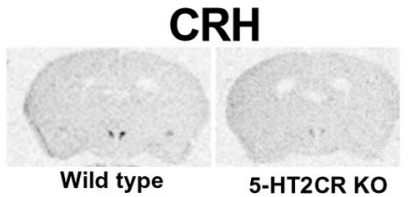

CART

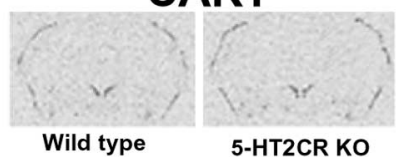

POMC

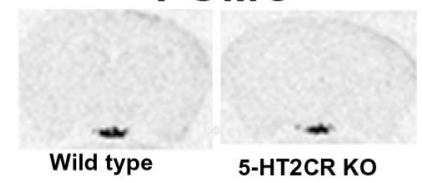

$\mathrm{MCH}$

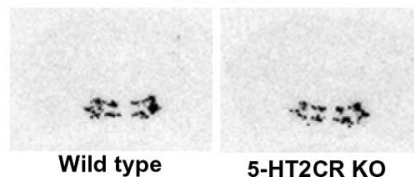

Figure 5. 5- $\mathrm{HT}_{2} \mathrm{R}$ knock-out mice displayed downregulated PVH CRH mRNA but similar PVH CART, ARC POMC, and LHA MCH mRNA expression compared with wild-type littermates. In situ hybridization of ${ }^{35}$ S-labeled CRH, CART, POMC, and MCH antisense probes was performed in adjacent coronal sections of wild-type (black bar) and 5- $\mathrm{HT}_{2} \mathrm{R} \mathrm{knock-0ut} \mathrm{(KO}$; white bar) littermate mouse brains. $\boldsymbol{a}, 5-\mathrm{HT}_{2} \mathrm{R}$ KO mice displayed reduced PVH CRH mRNA compared with wild-type littermates as determined by integrated density analysis of ${ }^{35} \mathrm{~S}$-labeled $\mathrm{CRH}$. The autoradiogram illustrates representative sections 0.82 caudal to bregma. $\boldsymbol{b}-\boldsymbol{d}$, In contrast, $5-\mathrm{HT}_{2} \mathrm{R} \mathrm{KO}$ and wild-type mice exhibited comparable levels of PVH ${ }^{35} \mathrm{~S}$-labeled CART ( $\boldsymbol{b}$; autoradiogram illustrates representative sections 0.82 caudal to bregma), similar levels of ARC ${ }^{35} \mathrm{~S}$ labeled POMC ( $\boldsymbol{c}$; autoradiogram illustrates representative sections 1.70 caudal to bregma), and comparable levels of LHA ${ }^{35}$ S-labeled MCH (d; autoradiogram illustrates representative sections 1.94 caudal to bregma). Data are expressed as mean \pm SEM. ${ }^{* *} p<0.01$, wild-type versus 5- $\mathrm{HT}_{2 \mathrm{C}} \mathrm{R} \mathrm{KO}$ mice.

ization in the $\mathrm{PVH}$ revealed that $5-\mathrm{HT}_{2 \mathrm{C}} \mathrm{R}$ knock-out mice displayed significantly reduced CRH mRNA expression compared with their wild-type littermates (Fig. $5 a)(p<0.01)$. We investigated the specificity of this effect by assessing expression of other hypothalamic neuropeptides in adjacent sections of tissue. Unlike $\mathrm{CRH}, 5-\mathrm{HT}_{2 \mathrm{C}} \mathrm{R}$ knock-out mice exhibited levels of $\mathrm{PVH}$ CART mRNA similar to wild-type littermates (Fig. 5b). Similarly, $5-\mathrm{HT}_{2 \mathrm{C}} \mathrm{R}$ knock-out and wild-type mice displayed similar levels of ARC POMC mRNA (Fig. 5c) and LHA MCH mRNA (Fig. 5d). Together, these data strongly support an integral role for the $5-\mathrm{HT}_{2 \mathrm{C}} \mathrm{Rs}$ in the regulation of CRH expression and in the subsequent release of CRH into the hypophyseal portal system.

\section{5-HT agonists require $5-\mathrm{HT}_{2 \mathrm{C}} \mathrm{Rs}$ to stimulate glucocorticoid release}

$\mathrm{CRH}$ release from the PVH begins a cascade of endocrine events in the HPA axis. Consistent with their effects on $\mathrm{CRH}$ release, $\mathrm{mCPP}$ and $\mathrm{D}$-fen significantly increase levels of plasma CORT (Sevy et al., 1994; Silverstone et al., 1994; Broocks et al., 2000). To determine whether $5-\mathrm{HT}_{2 \mathrm{C}} \mathrm{Rs}$ contribute to these actions, we compared 5-HT agonist-induced CORT release in $5-\mathrm{HT}_{2 \mathrm{C}} \mathrm{R}$ knock-out and wild-type mice. We first assessed basal CORT in $5-\mathrm{HT}_{2 \mathrm{C}} \mathrm{R}$-deficient mice and wild-type littermates at the onset of the light and dark cycle. As is well established in rodents, mice displayed higher plasma CORT during the dark compared with

light cycle. No significant phenotypic differences were found in basal plasma CORT (Fig. 6a). However, after 5-HT-induced HPA axis stimulation, a significant phenotypic difference in plasma CORT was observed. Of note, saline-treated mice displayed higher CORT in the mCPP study (Fig. 6b) compared with the D-fen study (Fig. 6c), and we attribute this variation to the use of different procedure rooms. Despite this, both $\mathrm{mCPP}$ (2.5 and 5.0 $\mathrm{mg} / \mathrm{kg})$ and D-fen $(3.0 \mathrm{mg} / \mathrm{kg})$ produced consistent and significant increases in CORT levels compared with saline treatment in wild-type mice (Fig. 6b,c) $(p<0.05)$. In contrast, $5-\mathrm{HT}_{2 \mathrm{C}} \mathrm{R}$ knock-out mice did not alter CORT in response to $\mathrm{MCPP}$ or D-fen (Fig. 6b,c). These data indicate that action at $5-\mathrm{HT}_{2 \mathrm{C}} \mathrm{Rs}$ contributes to 5-HT-induced activation of the HPA axis, affecting both the release of CRH and the subsequent release of CORT.

\section{Discussion}

A reciprocal functional interaction between the central 5-HT system and HPA axis has been shown to exist under normal physiological conditions and has been postulated to be of particular relevance in pathological states. Compounds used to increase 5-HT neurotransmission have been widely prescribed for the treatment of depression, panic disorder, and obesity, and some evidence suggests that the efficacy of these compounds may be related to their ability to correct concomitant dysregulation of the HPA axis (Linkowski et al., 1987; Brady et al., 1991). Indeed, compounds such as $\mathrm{MCPP}$ and D-fen both potently reduce food intake and enhance CRH and CORT release. Although not assessed here, it is intriguing to speculate that a mechanism through which 5-HT affects both feeding behavior and HPA axis activity is via regulation of $\mathrm{CRH}$ activity in the PVH.

Using complementary approaches in wild-type rats, wild-type mice, and mice with a 5-HTR gene disruption, here we demonstrate that 5-HT affects the HPA axis via regulation of $\mathrm{CRH}$ activity and expression through action at $5-\mathrm{HT}_{2 \mathrm{C}} \mathrm{Rs}$. Specifically, we observed that 5-HT-mimetic agents commonly used to stimulate glucocorticoid release significantly activated $\mathrm{CRH}$ expressing neurons, both in vivo and using electrophysiological techniques. Therefore, it is possible that although 5-HTimmunoreactive nerve terminals are not densely evident within the PVH (Sawchenko et al., 1983), the release of 5-HT is sufficient to substantially affect the activity of $\mathrm{CRH}$-containing neurons.

To determine which receptor(s) contribute to 5-HT activation of CRH neurons, we extracted the rostral to caudal extent of the PVH and compared expression of 5-HTR genes using microarray transcriptomics. The preponderance of research thus far using compounds such as $5-\mathrm{HT}_{2 \mathrm{C} / 2 \mathrm{~A}} \mathrm{R}$ agonist DOI and the highaffinity $5-\mathrm{HT}_{1 \mathrm{~A}} \mathrm{R}$ agonist $8-\mathrm{OH}$-DPAT has implicated $5-\mathrm{HT}_{2 \mathrm{~A}} \mathrm{Rs}$ and $5-\mathrm{HT}_{1 \mathrm{~A}} \mathrm{Rs}$ in 5-HT-induced ACTH and CORT release (Gilbert et al., 1988; Calogero et al., 1989, 1993; Pan and Gilbert, 1992; Zhang et al., 2004). We were therefore surprised that the 5-HTR gene transcript most highly expressed encoded the $\mathrm{G}_{\mathrm{q}}$ coupled $5-\mathrm{HT}_{2 \mathrm{C}} \mathrm{R}$, a receptor through which direct activation of $\mathrm{CRH}$-containing neurons could be achieved. We confirmed the abundant expression of $5-\mathrm{HT}_{2 \mathrm{C}} \mathrm{Rs}$ in the rat PVH using ISHH. The diffuse expression of $5-\mathrm{HT}_{2 \mathrm{C}}$ Rs in the $\mathrm{PVH}$ of rats and mice implicates this receptor in multiple PVH-regulated functions and behaviors. Of particular interest was the overlapping $5-\mathrm{HT}_{2 \mathrm{C}} \mathrm{R}$ mRNA distribution with CRH-containing neurons. Using dualneurohistochemical labeling, we observed that approximately one-half of CRH-expressing neurons coexpressed $5-\mathrm{HT}_{2 \mathrm{C}} \mathrm{Rs}$. We speculate that the stringency of our dual-labeling criteria produced an underestimate of the actual endogenous coexpression rate predicted by the in vivo and electrophysiological studies. 
Alternatively, the consistent mCPPinduced activation of CRH-containing neurons may involve action at another 5-HTR coexpressed with CRH, such as the $5-\mathrm{HT}_{2 \mathrm{~A}} \mathrm{Rs}$, which were not assessed by the GeneChip. However, a recent report suggests that $5-\mathrm{HT}_{2 \mathrm{~A}} \mathrm{Rs}$ are not critically involved in HPA axis activity, because the complete abolition of the $5-\mathrm{HT}_{2 \mathrm{~A}} \mathrm{R}$ gene does not impair or alter HPA axis function (Weisstaub et al., 2006).

The only other 5-HTR transcript identified as "present" in our sample was the $\mathrm{G}_{\mathrm{i}}$-coupled 5-HT ${ }_{1 \mathrm{D}}$ Rs. Of note, the $5-\mathrm{HT}_{1 \mathrm{D} / 1 \mathrm{~B}} \mathrm{R}$ agonist CP94253 significantly induced FOS-IR in the PVH (Lee et al., 2004). Although not investigated here, it is possible that $\mathrm{MCPP}$ may also influence $\mathrm{CRH}$ activity indirectly through action at PVH $5-\mathrm{HT}_{1 \mathrm{D}}$ Rs. For example, $5-\mathrm{HT}_{1 \mathrm{D}}$ Rs may be expressed in PVH neuronal cell bodies or processes, providing a local inhibitory input onto $\mathrm{CRH}-$ containing neurons, and thereby mCPP action at PVH 5- $\mathrm{HT}_{1 \mathrm{D}} \mathrm{Rs}$ may indirectly facilitate CRH activity. This possibility warrants additional consideration.

Contrary to expectation, we did not observe consistent or high $5-\mathrm{HT}_{1 \mathrm{~A}} \mathrm{R}$ transcript expression in the PVH. It is possible that 8-OH-DPAT may affect PVH CRH activity by reducing an inhibitory input arising from other brain regions via action at terminal $5-\mathrm{HT}_{1 \mathrm{~A}}$ Rs. Alternatively or additionally, 8-OH-DPAT may reduce the activity of the 5-HT transporter, thereby facilitating the action of $5-\mathrm{HT}$ at $\mathrm{PVH} \mathrm{CRH} 5-\mathrm{HT}_{2 \mathrm{C}} \mathrm{R}$-expressing neurons. 8-OH-DPAT also has some affinity for the $5-\mathrm{HT}_{2 \mathrm{C}} \mathrm{Rs}$ (pKi 5.2), in addition to the $5-\mathrm{HT}_{1 \mathrm{~A}} \mathrm{Rs}$ (pKi 8.7) (Hoyer 1989), and it is therefore conceivable that 8 -OH-DPAT may affect $\mathrm{CRH}$ release directly through action at $\mathrm{PVH} 5-\mathrm{HT}_{2 \mathrm{C}}$ Rs.

To discern the selective effect of action at $5-\mathrm{HT}_{2 \mathrm{C}} \mathrm{R}$ in $\mathrm{CRH}$ activity, we recorded from neurons in the presence of $\mathrm{mCPP}$ and the $5-\mathrm{HT}_{2 \mathrm{C}} \mathrm{R}$ antagonist $\mathrm{RS} 102221$. We observed that mCPP reliably depolarized the mpPVH neurons, an effect blocked by RS102221. These data suggest that 5-HT enhances the activity of $\mathrm{PVH} \mathrm{CRH}$ neurons via activation of $5-\mathrm{HT}_{2 \mathrm{C}} \mathrm{Rs}$. Moreover, $5-\mathrm{HT}_{2 \mathrm{C}} \mathrm{R}$ knock-out mice do not increase $\mathrm{CRH}$ release or $\mathrm{CRH}$ mRNA in response to $\mathrm{mCPP}$ and/or D-fen. Given that $\mathrm{mCPP}$ has affinity for multiple 5-HT receptors, and D-fen increases 5-HT availability at all receptors, these data strongly argue for the selective role of $5-\mathrm{HT}_{2} \mathrm{C}$ s in $\mathrm{CRH}$ release and expression. These findings do not appear to be a consequence of developmental compensatory changes in central 5-HT circuits, because $5-\mathrm{HT}_{2 \mathrm{C}} \mathrm{R}$ knock-out mice display levels of many 5-HT systemrelated genes similar to those of wild-type littermates (LopezGimenez et al., 2002). However, the possibility remains that our results may be influenced by a compensatory alteration in neurocircuitry affecting $\mathrm{CRH}$ neurons arising from the constitutive genetic ablation of the $5-\mathrm{HT}_{2 \mathrm{C}}$ Rs in the knock-out mice. For this reason, complementary studies were performed in wild-type rodents, and the data obtained support an integral role for $5-\mathrm{HT}_{2 \mathrm{C}} \mathrm{Rs}$ in 5-HT activation of CRH neurons.

The dramatic basal downregulation of $\mathrm{CRH}$ mRNA in the $5-\mathrm{HT}_{2 \mathrm{C}} \mathrm{R}$ knock-out mice indicates that 5-HT tonically regulates the expression of PVH CRH mRNA via action at these receptors. The normal basal CORT exhibited by the $5-\mathrm{HT}_{2 \mathrm{C}} \mathrm{R}$ knock-out mice in the face of PVH CRH mRNA suppression was surprising (Nonogaki et al., 1998), given that glucocorticoid feedback regulates PVH CRH mRNA (Herman et al., 1990). A possible expla- b
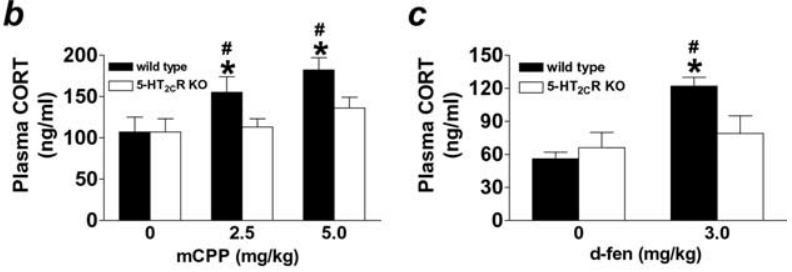

C e displayed normal circadian CORT but did not respond to mCPP- or D-fen-stimulated CORT
5-HT $\mathrm{R}$ knock-out (KO; white bars) mice displayed comparable levels of CORT measured in the light and dark cycles. In contrast, a significant genotypic difference in CORT release was b, $\boldsymbol{c}$, Both $\mathrm{mCPP}(\boldsymbol{b})$ and D-fen (c) significantly increased in vivo release of CORT in wild-type ersus $5-\mathrm{HT}_{2 \mathrm{C}} \mathrm{R}$ KO mice.

nation for this is that the combined activity of PVH arginine vasopressin (AVP) and CRH neurons is sufficient to induce adequate basal ACTH release to promote wild-type-like basal CORT in the $5-\mathrm{HT}_{2 \mathrm{C}}$ Rs knock-out mice, whereas under HPA axis stimulation, the deficiency in $\mathrm{CRH}$ is evident. Interestingly, genetic inactivation of $5-\mathrm{HT}_{3 \mathrm{~A}} \mathrm{Rs}$ has been demonstrated to reduce $\mathrm{PVH}$ AVP mRNA (Bhatnagar et al., 2004), suggesting that 5-HT may regulate multiple $\mathrm{PVH}$ neuropeptides. These data are consistent with our findings that both $\mathrm{mCPP}$ and $\mathrm{D}$-fen induced FOS-IR in non-CRH-labeled PVH neurons. Future studies are required to investigate whether $5-\mathrm{HT}_{2 \mathrm{C}} \mathrm{Rs}$ knock-out mice also display altered HPA axis activation after behavioral stress stimuli and the extent to which the downregulated CRH mRNA affects HPA axis function under varying physiological conditions of HPA axis activity.

Altered HPA axis function in $5-\mathrm{HT}_{2 \mathrm{C}} \mathrm{R}$ knock-out mice may be relevant to the enhanced antidepressant-like effect of selective serotonin reuptake inhibitors observed in $5-\mathrm{HT}_{2 \mathrm{C}} \mathrm{R}$ knock-out mice (Cremers et al., 2004) and the hyperphagia and obesity phenotype (Tecott et al., 1995; Nonogaki et al. al., 1998). In light of these phenotypic results, it is possible that $5-\mathrm{HT}_{2 \mathrm{C}} \mathrm{R}$-induced $\mathrm{CRH}$ activity may be particularly germane in pathological states such as depression and obesity.

In summary, we show for the first time that $5-\mathrm{HT}_{2 \mathrm{C}} \mathrm{Rs}$ are not only expressed in $\mathrm{CRH}$-containing neurons in the $\mathrm{PVH}$ but that 5 -HT circuits regulate the expression of PVH CRH mRNA. We further demonstrate that $5-\mathrm{HT}_{2 \mathrm{C}} \mathrm{R}$-deficient mice exhibit blunted CRH and CORT release after 5-HT-induced HPA axis stimulation. The data presented define a mechanism underlying the longstanding observation of 5-HT-regulated glucocorticoid release and provide insight into upstream circuits affecting the neuroendocrine response to stress. These findings provide a new model to investigate the concomitant dysregulation of central 5-HT circuits and the HPA axis in the etiology and treatment of pathological states related to mood and energy homeostasis.

\section{References}

Bagdy G, Calogero AE, Aulakh CS, Szemeredi K, Murphy DL (1989) Longterm cortisol treatment impairs behavioral and neuroendocrine responses to 5-HT1 agonists in the rat. Neuroendocrinology 50:241-247.

Bhatnagar S, Sun LM, Raber J, Maren S, Julius D, Dallman MF (2004) Changes in anxiety-related behaviors and hypothalamic-pituitaryadrenal activity in mice lacking the 5-HT-3A receptor. Physiol Behav 81:545-555.

Brady LS, Whitfield Jr HJ, Fox RJ, Gold PW, Herkenham M (1991) Longterm antidepressant administration alters corticotropin-releasing hormone, tyrosine hydroxylase, and mineralocorticoid receptor gene expression in rat brain. Therapeutic implications. J Clin Invest 87:831-837.

Broocks A, Bandelow B, George A, Jestrabeck C, Opitz M, Bartmann U, Gleiter CH, Meineke I, Roed IS, Ruther E, Hajak G (2000) Increased 
psychological responses and divergent neuroendocrine responses to $\mathrm{m}-\mathrm{CPP}$ and ipsapirone in patients with panic disorder. Int Clin Psychopharmacol 15:153-161.

Calogero AE, Bernardini R, Margioris AN, Bagdy G, Gallucci WT, Munson PJ, Tamarkin L, Tomai TP, Brady L, Gold PW, Chrousos GP (1989) Effects of serotonergic agonists and antagonists on corticotropinreleasing hormone secretion by explanted rat hypothalami. Peptides 10:189-200.

Calogero AE, Bagdy G, Moncada ML, D’Agata R (1993) Effect of selective serotonin agonists on basal, corticotrophin-releasing hormone- and vasopressin-induced ACTH release in vitro from rat pituitary cells. J Endocrinol 136:381-387.

Cheung CC, Clifton DK, Steiner RA (1997) Proopiomelanocortin neurons are direct targets for leptin in the hypothalamus. Endocrinology 138:4489-4492.

Couceyro PR, Koylu EO, Kuhar MJ (1997) Further studies on the anatomical distribution of CART by in situ hybridization. J Chem Neuroanat 12:229-241.

Cowley MA, Chen C, Clarke IJ (1999a) Estrogen transiently increases delayed rectifier, voltage-dependent potassium currents in ovine gonadotropes. Neuroendocrinology 69:254-260.

Cowley MA, Pronchuk N, Fan W, Dinulescu DM, Colmers WF, Cone RD (1999b) Integration of NPY, AGRP, and melanocortin signals in the hypothalamic paraventricular nucleus: evidence of a cellular basis for the adipostat. Neuron 24:155-163.

Cowley MA, Smith RG, Diano S, Tschop M, Pronchuk N, Grove KL, Strasburger CJ, Bidlingmaier M, Esterman M, Heiman ML, Garcia-Segura LM, Nillni EA, Mendez P, Low MJ, Sotonyi P, Friedman JM, Liu H, Pinto S, Colmers WF, Cone RD, et al. (2003) The distribution and mechanism of action of ghrelin in the CNS demonstrates a novel hypothalamic circuit regulating energy homeostasis. Neuron 37:649-661.

Cremers TI, Giorgetti M, Bosker FJ, Hogg S, Arnt J, Mork A, Honig G, Bogeso KP, Westerink BH, den Boer H, Wikstrom HV, Tecott LH (2004) Inactivation of $5-\mathrm{HT}(2 \mathrm{C})$ receptors potentiates consequences of serotonin reuptake blockade. Neuropsychopharmacology 29:1782-1789.

Elias CF, Lee C, Kelly J, Aschkenasi C, Ahima RS, Couceyro PR, Kuhar MJ, Saper CB, Elmquist JK (1998) Leptin activates hypothalamic CART neurons projecting to the spinal cord. Neuron 21:1375-1385.

Elmquist JK, Scammell TE, Jacobson CD, Saper CB (1996) Distribution of Fos-like immunoreactivity in the rat brain following intravenous lipopolysaccharide administration. J Comp Neurol 371:85-103.

Fuller RW, Snoddy HD (1980) Effect of serotonin-releasing drugs on serum corticosterone concentration in rats. Neuroendocrinology 31:96-100.

Fuller RW, Snoddy HD (1990) Serotonin receptor subtypes involved in the elevation of serum corticosterone concentration in rats by direct- and indirect-acting serotonin agonists. Neuroendocrinology 52:206-211.

Gibbs DM, Vale W (1983) Effect of the serotonin reuptake inhibitor fluoxetine on corticotropin-releasing factor and vasopressin secretion into hypophysial portal blood. Brain Res 280:176-179.

Gilbert F, Brazell C, Tricklebank MD, Stahl SM (1988) Activation of the 5-HT1A receptor subtype increases rat plasma ACTH concentration. Eur J Pharmacol 147:431-439.

Gold PW, Chrousos GP (1985) Clinical studies with corticotropin releasing factor: implications for the diagnosis and pathophysiology of depression, Cushing's disease, and adrenal insufficiency. Psychoneuroendocrinology 10:401-419.

Guillemin R, Rosenberg B (1955) Humoral hypothalamic control of anterior pituitary: a study with combined tissue cultures. Endocrinology 57:599-607.

Heisler LK, Chu HM, Brennan TJ, Danao JA, Bajwa P, Parsons LH, Tecott LH (1998) Elevated anxiety and antidepressant-like responses in serotonin 5-HT1A receptor mutant mice. Proc Natl Acad Sci USA 95:15049-15054.

Heisler LK, Cowley MA, Tecott LH, Fan W, Low MJ, Smart JL, Rubinstein M, Tatro JB, Marcus JN, Holstege H, Lee CE, Cone RD, Elmquist JK (2002) Activation of central melanocortin pathways by fenfluramine. Science 297:609-611.

Heisler LK, Cowley MA, Kishi T, Tecott LH, Fan W, Low MJ, Smart JL, Rubinstein M, Tatro JB, Zigman JM, Cone RD, Elmquist JK (2003) Central serotonin and melanocortin pathways regulating energy homeostasis. Ann NY Acad Sci 994:169-174.

Heisler LK, Jobst EE, Sutton GM, Zhou L, Borok E, Thornton-Jones Z, Liu HY, Zigman JM, Balthasar N, Kishi T, Lee CE, Aschkenasi CJ, Zhang C-Y,
Yu J, Boss O, Mountjoy KG, Clifton PG, Lowell BB, Friedman JM, Horvath $\mathrm{T}$, et al. (2006) Serotonin reciprocally regulates melanocortin neurons to modulate food intake. Neuron 51:239-249.

Herman JP, Wiegand SJ, Watson SJ (1990) Regulation of basal corticotropin-releasing hormone and arginine vasopressin messenger ribonucleic acid expression in the paraventricular nucleus: effects of selective hypothalamic deafferentations. Endocrinology 127:2408-2417.

Hoyer D (1989) 5-Hydroxytryptamine receptors and effector coupling mechanisms in peripheral tissues. In: Peripheral actions of 5-HT (Fozard J, ed), pp 72-99. Oxford: Oxford UP.

Hu SB, Lightman SL, Tannahill LA (1992) 5-Hydroxytryptamine stimulates corticosteroid-sensitive CRF release from cultured foetal hypothalamic cells. Role of protein kinases. Brain Res 574:266-270.

Javed A, Kamradt MC, Van de Kar LD, Gray TS (1999) D-Fenfluramine induces serotonin-mediated Fos expression in corticotropin-releasing factor and oxytocin neurons of the hypothalamus, and serotoninindependent Fos expression in enkephalin and neurotensin neurons of the amygdala. Neuroscience 90:851-858.

Jorgensen H, Knigge U, Kjaer A, Muller M, Warberg J (2002) Serotonergic stimulation of corticotropin-releasing hormone and proopiomelanocortin gene expression. J Neuroendocrinol 14:788-795.

Kelly WF, Checkley SA, Bender DA (1980) Cushing's syndrome, tryptophan and depression. Br J Psychiatry 136:125-132.

Kennet GA, Wood MD, Bright F, Trail B, Riley G, Holland V, Avenell KY, Stean T, Upton N, Bromidge S, Forbes IT, Brown AM, Middlemiss DN, Blackburn TP (1997) SB242084, a selective and brain penetrant 5-HT2C receptor antagonist. Neuropharmacology 36:609-620.

Koe KB, Nielsen JA, Macor JE, Heym J (1992) Biochemical and behavioural studies of the 5-HT1B receptor agonist, CP-94,253. Drug Dev Res 26:241-250.

Laferrere B, Lahlou N, Saltiel H, Roger M, Basdevant A, Oppert JM, GuyGrand B (1994) Hypersensitivity of the corticotropic axis to the serotoninergic agent clomipramine in obese women. Obes Res 2:328-336.

Laflamme N, Bovetto S, Richard D, Rivest S (1996) Effect of dexfenfluramine on the transcriptional activation of CRF and its type 1 receptor within the paraventricular nucleus of the rat hypothalamus. Br J Pharmacol 117:1021-1034.

Lee MD, Somerville EM, Kennett GA, Dourish CT, Clifton PG (2004) Tonic regulation of satiety by $5-\mathrm{HT}$ receptors in the mouse: converging evidence from behavioural and c-fos immunoreactivity studies. Eur J Neurosci 19:3017-3025.

Li BH, Rowland NE (1993) Dexfenfluramine induces Fos-like immunoreactivity in discrete brain regions in rats. Brain Res Bull 31:43-48.

Linkowski P, Mendlewicz J, Kerkhofs M, Leclercq R, Golstein J, Brasseur M, Copinschi G, Van Cauter E (1987) 24-hour profiles of adrenocorticotropin, cortisol, and growth hormone in major depressive illness: effect of antidepressant treatment. J Clin Endocrinol Metab 65:141-152.

Liposits Z, Phelix C, Paull WK (1987) Synaptic interaction of serotonergic axons and corticotropin releasing factor (CRF) synthesizing neurons in the hypothalamic paraventricular nucleus of the rat. A light and electron microscopic immunocytochemical study. Histochemistry 86:541-549.

Liu H, Kishi T, Roseberry AG, Cai X, Lee CE, Montez JM, Friedman JM, Elmquist JK (2003) Transgenic mice expressing green fluorescent protein under the control of the melanocortin-4 receptor promoter. J Neurosci 23:7143-7154.

Lopez-Gimenez JF, Tecott LH, Palacios JM, Mengod G, Vilaro MT (2002) Serotonin 5- HT (2C) receptor knockout mice: autoradiographic analysis of multiple serotonin receptors. J Neurosci Res 67:69-85.

Lucki I (1998) The spectrum of behaviors influenced by serotonin. Biol Psychiatry 44:151-162.

Molineaux SM, Jessell TM, Axel R, Julius D (1989) 5-HT1c receptor is a prominent serotonin receptor subtype in the central nervous system. Proc Natl Acad Sci USA 86:6793-6797.

Nonogaki K, Strack AM, Dallman MF, Tecott LH (1998) Leptinindependent hyperphagia and type 2 diabetes in mice with a mutated serotonin 5-HT2C receptor gene. Nat Med 4:1152-1156.

Nonogaki K, Ohashi-Nozue K, Oka Y (2006) A negative feedback system between brain serotonin systems and plasma active ghrelin levels in mice. Biochem Biophys Res Commun 341:703-707.

Pan L, Gilbert F (1992) Activation of 5-HT1A receptor subtype in the paraventricular nuclei of the hypothalamus induces CRH and ACTH release in the rat. Neuroendocrinology 56:797-802. 
Paxinos G, Franklin KBJ (2001) The mouse brain, in stereotaxic coordinates, Ed 2. San Diego: Academic.

Porter RH, Benwell KR, Lamb H, Malcolm CS, Allen NH, Revell DF, Adams DR, Sheardown MJ (1999) Functional characterization of agonists at recombinant human 5-HT2A, 5-HT2B and 5-HT2C receptors in CHO-K1 cells. Br J Pharmacol 128:13-20.

Porter RJ, Gallagher P, Watson S, Young AH (2004) Corticosteroidserotonin interactions in depression: a review of the human evidence. Psychopharmacology (Berl) 173:1-17.

Pronchuk N, Beck-Sickinger AG, Colmers WF (2002) Multiple NPY receptors inhibit $\mathrm{GABA}(\mathrm{A})$ synaptic responses of rat medial parvocellular effector neurons in the hypothalamic paraventricular nucleus. Endocrinology 143:535-543.

Qu D, Ludwig DS, Gammeltoft S, Piper M, Pelleymounter MA, Cullen MJ, Mathes WF, Przypek R, Kanarek R, Maratos-Flier E (1996) A role for melanin-concentrating hormone in the central regulation of feeding behaviour. Nature 380:243-247.

Raber J, Bloom FE (1994) IL-2 induces vasopressin release from the hypothalamus and the amygdala: role of nitric oxide-mediated signaling. J Neurosci 14:6187-6195.

Raber J, Koob GF, Bloom FE (1995) Interleukin-2 (IL-2) induces corticotropin-releasing factor (CRF) release from the amygdala and involves a nitric oxide-mediated signaling; comparison with the hypothalamic response. J Pharmacol Exp Ther 272:815-824.

Richard D, Rivest S, Rivier C (1992) The 5-hydroxytryptamine agonist fenfluramine increases Fos-like immunoreactivity in the brain. Brain Res 594:131-137.

Sawchenko PE, Swanson LW, Steinbusch HW, Verhofstad AA (1983) The distribution and cells of origin of serotonergic inputs to the paraventricular and supraoptic nuclei of the rat. Brain Res 277:355-360.

Sevy S, Brown SL, Wetzler S, Kotler M, Molcho A, Plutchik R, van Praag HM
(1994) Effects of alprazolam on increases in hormonal and anxiety levels induced by meta-chlorophenylpiperazine. Psychiatry Res 53:219-229.

Silverstone PH, Rue JE, Franklin M, Hallis K, Camplin G, Laver D, Cowen PJ (1994) The effects of administration of mCPP on psychological, cognitive, cardiovascular, hormonal and MHPG measurements in human volunteers. Int Clin Psychopharmacol 9:173-178.

Singewald N, Salchner P, Sharp T (2003) Induction of c-Fos expression in specific areas of the fear circuitry in rat forebrain by anxiogenic drugs. Biol Psychiatry 53:275-283.

Spiess J, Rivier J, Rivier C, Vale W (1981) Primary structure of corticotropin-releasing factor from ovine hypothalamus. Proc Natl Acad Sci USA 78:6517-6521.

Tecott LH, Sun LM, Akana SF, Strack AM, Lowenstein DH, Dallman MF, Julius D (1995) Eating disorder and epilepsy in mice lacking 5-HT2c serotonin receptors. Nature 374:542-546.

Vielhaber K, Riemann D, Feige B, Kuelz A, Kirschbaum C, Voderholzer U (2005) Impact of experimentally induced serotonin deficiency by tryptophan depletion on saliva cortisol concentrations. Pharmacopsychiatry 38:87-94.

Weisstaub NV, Zhou M, Lira A, Lambe E, González-Maeso J, Hornung J-P, Sibille E, Underwood M, Itohara S, Dauer WT, Ansorge MS, Morelli E, Mann JJ, Toth M, Aghajanian G, Sealfon SC, Hen R, Gingrich JA (2006) Cortical 5-HT2A receptor signaling modulates anxiety-like behaviors in mice. Science 313:536-540.

Yamamoto H, Kishi T, Lee CE, Choi BJ, Fang H, Hollenberg AN, Drucker DJ, Elmquist JK (2003) Glucagon-like peptide-1-responsive catecholamine neurons in the area postrema link peripheral glucagon-like peptide-1 with central autonomic control sites. J Neurosci 23:2939-2946.

Zhang Y, Gray TS, D’Souza DN, Carrasco GA, Damjanoska KJ, Dudas B, Garcia F, Zainelli GM, Sullivan Hanley NR, Battaglia G, Muma NA, Van de Kar LD (2004) Desensitization of 5-HT1A receptors by 5-HT2A receptors in neuroendocrine neurons in vivo. J Pharmacol Exp Ther 310:59-66. 